\title{
working-class Lesbian life: classed outsiders
}

Yvette Taylor, Palgrave Macmillan, Basingstoke, 2007, 220 pp.,

ISBN 13: 978-0-230-00871, £45.00 (hardback)

Although the literature on lesbian, gay, bisexual and transgendered people's lives is slowly being developed, there still remain substantial gaps to be addressed. Taylor's research is to be welcomed, given its focus on working-class lesbians. However, she is not solely concerned with 'filling a gap' in the social sciences literature but in asking why working-class lesbians 'weren't included in the first place?'. She argues that this is primarily because the production of knowledge remains a 'classed practice' whereby working-class voices are rarely heard. Her study aims to forge a new space to think about the interconnection between class and sexuality.

Taylor sets out by exploring 'class definitions, meanings and erasures' and provides a critique of research, which suggests that class belongs to a distant past. She argues that pronouncements of the demise of class division are in fact 'classed'. She is determined to keep class as central to her analysis although she acknowledges that there remain difficulties of definition. However, she argues that this does not pose a problem for her study because her concern is not about what class is, or could be, but rather what class does. Her focus is on working-class lesbians' experiences of class and the meanings which the women themselves attribute to it. Taylor turns to Bourdieu's (1984) theoretical model of classed habitus and classed capitals to assist her in exploring the significance of both class and sexuality. Recognising that Bourdieu's social theory has little to say about gender or sexuality, she seeks to extend it by theoretically establishing the intersection of class and sexuality in order to reach beyond what she sees as an impasse created by a 'dichotomised materialist/queer theorisation of sexuality'.

Her aim is to theoretically establish the intersection of class and sexuality. As someone who defines as a working-class lesbian, she wishes to answer the question of what it means to be both. Her study involves fifty-three women who define as working-class lesbians. In the empirical chapters she aims to show that the women had 'agency, opinions and choices'. Taylor divides her material into chapters on family background, schooling, work experiences, working-class areas and communities, leisure activities, scene spaces and intimate relationships.

She begins by identifying how working-class lesbians' class identifications were formed in childhood through an awareness of parental employment and unemployment, communal solidarity and/or vulnerability and financial hardship and difference. The study then examines the women's experiences of growing up in working-class families and communities and attending what she describes as '(classed) schools'. Although illuminating, for the most part discussion at the outset focuses solely on class rather than the intersection of class and sexuality. 
However, in the discussion of school experiences, the study begins to identify the way in which interviewees could be positioned as 'failures' both in terms of their class positions and sexual identities. This intersectional analysis successfully considers the implications of both class and sexuality and illustrates the way such experiences made it difficult for many of the women to positively claim their classed and sexual 'difference' as they felt rendered silent and/or deviant within the school and their community.

The chapter on employment also successfully developed an intersectional analysis so illustrating the ways in which both class and sexuality may constrain and affect employment choices. The 'failures' of the education system meant that most of the women in the study found their career horizons limited and in the main faced low-paid, 'feminised' and often insecure work or unemployment. Workplaces were viewed as 'restrictive environments' particularly if workplace performance involved a specifically heterosexual (and classed) image.

Taylor concludes that Bourdieu's (1984) insights on social capital and habitus assist in understanding the 'material, embodied and subjective consequences of occupying both working-class and lesbian identities'; however, this was less successfully demonstrated in the three remaining chapters. These sought to consider the spatial aspects of identification. Working-class space was described as 'devalued territories' to which women felt loyalty, although some had felt compelled to move away from these spaces because of their sexuality. This was in contrast to the 'trendy', commercial, gay scene which a number of the women said they felt excluded from on grounds of both gender and class. Sadly, the study concludes that this resulting lack of infrastructure meant that some of the women reported a 'degree of isolation and vulnerability' in sustaining relationships and networks. Not enough was said in the study about positive sources of support.

Taylor's study is useful in highlighting that, notwithstanding some triumphs, to be on the outside on both counts of class and sexuality can be a significant burden to bear. She concludes that her book points to ways that class and sexuality connect in the lives of working-class lesbians. I would agree that the study successfully achieves the former but that it was not always successful in achieving the latter. The intersectional analysis of class and sexuality was not always achieved. Notwithstanding this reservation, Taylor's book does provide a timely reminder of the importance of class in analysis generally and to lesbian, gay, bisexual and transgender research more specifically.

\section{reference}

Fiona Colgan

Bourdieu, P. (1984) Distinction: A Social Critique of the Judgement of Taste, London: Routledge.

doi: $10.1057 / f r .2009 .51$ 